\title{
Industrial Composting of Commingled Municipal Solid Waste: A Case Study of Shiraz City, Iran
}

\author{
Sama Azadi ${ }^{1}$, Ayoub Karimi-Jashni ${ }^{1 *}$, Nasser Talebbeydokhti ${ }^{1}$, Rouhollah Khoshbakht ${ }^{2}$, Azadeh \\ Binaee Haghighi ${ }^{2}$
}

${ }^{1}$ Department of Civil and Environmental Engineering, School of Engineering, Shiraz University, Shiraz, Fars, Iran

${ }^{2}$ Waste Management Organization of Shiraz Municipality, Shiraz, Fars, Iran

Received: $19 / 04 / 2020$

Accepted: 12/09/2020

Published: 20/12/2020

\begin{abstract}
Composting is a preferable treatment option for putrescible waste disposal. In the small-scale composting, the control of the process is easy and high quality compost is usually produced while the conditions of industrial composting and small-scale composting are so different especially in developing country that municipal solid waste (MSW) is collected as commingled. Unfortunately, there is still a lack of information and experiences regarding the successful industrial composting from commingled municipal solid waste (CMSW). Therefore, this study was conducted on the compost production from CMSW in Shiraz City, Iran, with the composting capacity of 100 tonnes per day. The common process of windrow composting was modified for industrial composting in Shiraz City. The efficiency of the modified process was assessed using physical, chemical, and economic analyses. In addition, the maturity and stability of produced compost was evaluated using different indices such as fertilizing index (FI), clean index (CI), static respiration index (SRI), cumulative respiration index (CRI), and $\mathrm{C}-\mathrm{CO}_{2}$ production index $\left(\mathrm{C}-\mathrm{CO}_{2}\right.$ Index). Finally, solutions and suggestions were presented to improve the system performance. Results showed that although the input putrescible waste to composting site has low homogeneity, produced compost in Shiraz City has a "good" quality. The produced compost with FI and CI of about 4.2 and 3.6, respectively, has high fertilizing potential and medium heavy metal content and can be sold without any restriction. Based on the economic analysis, poor marketing, strategies of bad marketing, lack of public awareness, and visible impurities, in spite of complying with the required standards, are the main reasons for the low sale price. The results of this study can be valuable for industrial composting in the cities where wastes are not separated at source.
\end{abstract}

Keywords: Industrial composting, Commingled municipal solid waste, Sorting center, Economical analysis

\section{Introduction}

Putrescible waste is the main fraction of MSW stream in developing countries (1-5). Putrescible waste disposal in a landfill leads to catastrophic environmental impacts such as global warming by greenhouse gases emission and groundwater contamination by toxic leachate generation (1, 6-11). Furthermore, putrescible waste generation has been increased with population, and serious environmental threats are predicted to increase in the future $(8,12,13)$. For these reasons, a sound strategy toward sustainable MSW management is the separation and treatment of putrescible waste.

Various treatment methods such as incineration, anaerobic digestion, bioelectrochemical systems, and composting have been applied for waste treatment $(12,14-20)$. However, composting is a preferred treatment option for putrescible waste disposal, especially in large cities $(21,22)$. Composting not only reduces negative environmental impacts but also generates a good product, namely compost, useful for plants and soil structure (10, $13,22-25)$. In the composting process, organic matters pass through a thermophilic phase, which is fostered by the biological activity and are mineralized to $\mathrm{CO}_{2}, \mathrm{NH}_{3}, \mathrm{H}_{2} \mathrm{O}$, and incomplete humification $(13,26)$. If the effective parameters in the process of mineralization are adjusted, stable, storable, and transportable compost will be obtained. Otherwise, immature compost will be produced that adversely affects soil environment and plant growth.

Generally speaking, compost quality is described based on its stability and maturity. Maturity relates to the phytotoxicity aspects of compost and determines its ability to be used effectively as soil fertilizer for the growth of plants. Stability which relates to the microbial decomposition or microbial respiration activity determines the resistance of the compost organic matter against further microbial decomposition.

Several researchers have investigated the composting process of MSW. Siles-Castellano et al. (2020) studied the maturity of produced compost from mixed MSW in the Southeast of Spain. They concluded that the phytotoxicity of MSW never lost during composting process due to the high heavy metal content of MSW (27). Cassero et al. (2019) assessed the compost stability and maturity during the composting process from $50 \mathrm{t} / \mathrm{d}$ source sorted

*Corresponding author: Ayoub Karimi-Jashni, Department of Civil and Environmental Engineering, School of Engineering, Shiraz University, Shiraz, Fars, Iran. E-mail: karimi.article.2015@gmail.com 
the organic fraction of MSW in the South of Italy. They concluded that the quality parameters fulfilled the requirements of the Italian legislation but plastic content occasionally exceeded the threshold limit values. In addition, the produced compost was moderately stable and needed more aeration (28).

Malamis et al. (2017) studied the composting process from segregated household food waste for a selected area of Attica Region with 3,700 households. Their results indicated that heavy metal concentrations were within the set limits and the produced compost was free of pathogens. The compost had sufficient organic matter for soil fertilization, but considerable physical impurities (mainly glass) were detected in the compost due to the limited pre-treatment. Awasthi et al. (2014) investigated the impact of turning frequency and fungal consortium on the produced compost from 5 ton MSW. They separately collected vegetables, food, garden, and office waste from eight different zones of Jabalpur city, India. The mixing of these wastes was placed in four windrows with $5 \mathrm{~m}$ length, $1 \mathrm{~m}$ width, and $1.4 \mathrm{~m}$ height. Based on their results, inoculation of fungal consortium with weekly turning frequency accelerated the production of mature compost with low phytotoxicity.

A literature survey specifies that the majority of studies carried out on compost production from MSW are on a small scale while the conditions of industrial composting and small-scale composting are so different. In the small-scale composting, the quality control of compost through the process is easy and the produced compost usually has excellent quality. Although producing high-quality composts are achievable in industrial composting, the composition and characteristics of final products are usually very variable especially in developing country that MSW is collected as commingled (29) and putrescible waste is separated in the CMSWSC. When MSW is collected as commingled, different types of waste are mixed together thoroughly and compacted during transportation. This causes that the separated putrescible waste in the CMSWSC which is the feed of composting plant does not possess desirable quality and homogeneity. Since there is still a lack of information and experiences regarding industrial composting process from CMSW, the management and quality control of the process in these conditions is so difficult and faces tremendous problems (8). Therefore, this study aims at presenting a modified industrial composting method from CMSW, evaluating the quality of produced compost, and investigating the challenges of this process. This method is currently being implemented in Shiraz City, Iran, with the composting capacity of $100 \mathrm{t} / \mathrm{d}$. In this study, first, the modified process of compost production from CMSW is presented. Then, the effectiveness and efficiency of the composting process with regard to the physical, chemical, and biological parameters are investigated. Next, the maturity of produced compost is evaluated based on the FI and CI. In addition, the stability of produced compost is assessed based on the SRI, CRI, and $\mathrm{C}-\mathrm{CO}_{2}$ Index. After that, Considering the incomes and costs of composting process from CMSW in the years of 2013 to 2016, economical analysis is conducted. Finally, solutions and suggestions are presented to improve the system performance.

\section{Materials and methods}

\subsection{Solid waste management in Shiraz City}

Shiraz City is located in the southwest of Iran with hot and semi-arid climate. Shiraz has a population of nearly 1.6 million and they generate 1,000 tonnes CMSW every day. Fig. 1 shows the mean percentage of CMSW components in Shiraz City. Among the generated CMSW, putrescible waste, including yard, food, and fruit waste, is the most substantial proportion $(66 \%)$. The rest of the waste is paper, plastic, glass, metal, and others. Shiraz City is $224 \mathrm{~km}^{2}$ in area and divided into ten municipality districts. Solid waste collection frequency is every other night with the scheme of door to door. CMSW is collected by truck and transferred to a transfer station and then to a processing site at Barmshoor site.

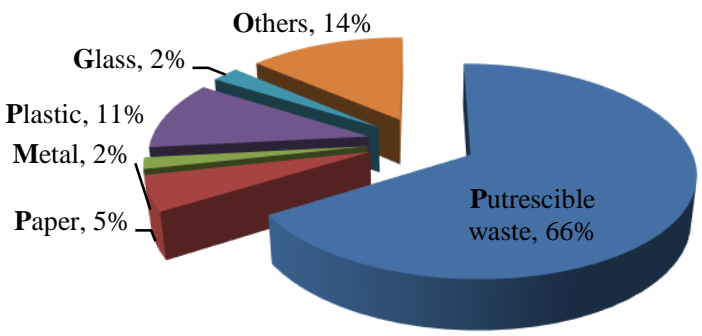

Figure. 1: Mean percentage of CMSW components in Shiraz City

There are MSW landfill site, administrative office, research laboratory, biogas power plant, CMSWSC, leachate collection ponds, and composting and vermicomposting sites in the processing site at Barmshoor site. $50 \%$ of collected solid waste is transferred to CMSWSC, and the rest of it is transferred to the landfill site. At the CMSWSC, the putrescible fraction of CMSW is separated and transferred to composting site. It is noteworthy that the green waste of florists, fruit, and vegetable shops is separately collected and transferred to vermicomposting site.

\subsection{Sorting process in the CMSWSC}

Two separate solid waste sorting lines are in operation in the CMSWSC. The first line has been in operation since 2013 and the second line since 2016. Each sorting line has the processing capacity of 250 tonnes CMSW per day. Five hundred tonnes of CMSW is transferred to the CMSWSC, and two front-end loaders dump CMSW gradually on conveyor belts. As observed in Fig. 2, in the first line, workers manually tear bags, and in the second line, the bags are torn by a device. Then, wastes pass through two trommel screens. Wastes, which are generally putrescible and smaller than $6 \mathrm{~cm}$, pass through the openings of screens. Larger wastes are transferred to a separation area by conveyor belts. In this area, workers manually remove bottles and recyclable materials. Remaining wastes pass through a magnet for metal collection. Then, they pass through an air separation device for plastic bag removal. Remaining wastes, called rejected wastes, are loaded and transferred to the landfill. Putrescible wastes pass through a magnet for metal collection. In the first line, there is one magnet, and in the second line, there are two magnets. Finally, putrescible materials are loaded and transferred to a compost production site.

\subsection{The modified process of composting in Shiraz City}

Fig. 3 shows the methodology flowchart of industrial composting in Shiraz City. 


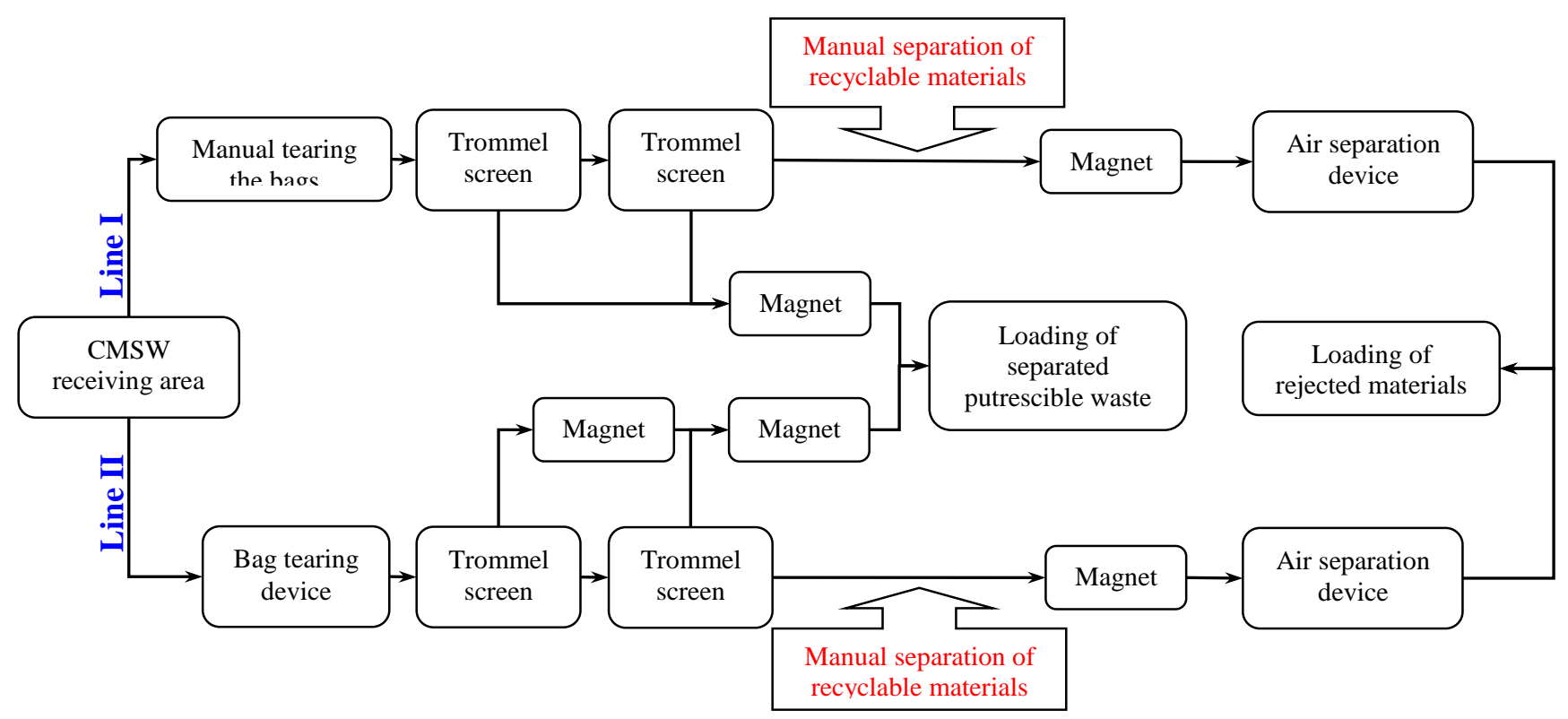

Figure. 2: A schematic view of CMSWSC in Shiraz City

About 500 tonnes of CMSW is fed to the CMSWSC every day (250 tonnes for each line). About 220 to 300 tonnes of separated putrescible waste is transferred to the composting site every day. This waste is placed daily in a windrow with $200 \mathrm{~m}$ length, $4.5 \mathrm{~m}$ width, and $1.3 \mathrm{~m}$ height. After initial aeration, the temperature and humidity of windrows are measured. Based on the temperature and humidity variation, aeration program of windrows is determined. Usually, aeration is conducted twice in the first week and once a week after that. Windrows are aerated by Turner Topturn X53. The purpose of aeration is to control the temperature in the thermophilic range and help the microbial activities.

Since Shiraz City is located in a dry climate, moisture is a limiting factor in the aeration of windrows. After four first weeks, the windrows are usually merged to keep their moisture and complete the thermophilic stage. Usually after 60 days, the transformed wastes are transferred to a secondary fermentation site for at least two weeks. After the completion of fermentation, produced materials are sieved to remove non-putrescible materials such as glass, metals, sand, stone, and textiles. Finally, produced compost is screened to classify into two sizes of smaller than $5 \mathrm{~mm}(0-5)$ and smaller than $15 \mathrm{~mm}(0-15)$.

\subsection{The quality grade of the produced compost}

Due to the high number of quality control parameters and the differences in the importance of these parameters, it is difficult to judge the overall quality of the produced compost. To tackle this problem, indicators are required to evaluate the quality and maturity of the compost based on its chemical properties and effectiveness in improving the soil properties. Saha et al. (2012) proposed a method for determining the overall quality of the produced compost based on two indices of Fertilizing Index (FI) and Clean Index (CI). In FI, the effect of some chemical properties of compost such as organic carbon, total nitrogen, phosphorus, potassium, and $\mathrm{C} / \mathrm{N}$ ratio on soil fertility is considered. For calculating this index, two factors of "desirability" and "importance" are assigned to each parameter.

For determining the desirability factor (DF), the possible values of each parameter are divided into five categories and each category is assigned a numeric value of 1 to 5 with regard to desirability. For determining the importance factor (IF), based on scientific information and the role of each parameter in soil fertility, one weight is assigned to each parameter. Table 1 shows the values of DF and IF for each parameter. As observed, the organic carbon is the most important parameter; because this parameter directly affects the water holding capacity, porosity, and structure of soil and increases the biological activity of soil. Although nitrogen, phosphorus, and potassium are three essential nutrients for higher crop productivity, potassium is less critical than others. So, potassium is assigned lower IF than phosphorus and nitrogen. The FI of composts is calculated as shown in Eq. 1:

Fertilizing Index $=\frac{\sum_{i=1}^{5} D F_{i} . I F_{i}}{\sum_{i=1}^{5} I F_{i}}$

$\mathrm{CI}$ is an indicator for the compost cleanliness regarding some heavy metals such as zinc, cadmium, chromium, copper, lead, and nickel. To calculate this index, the desirability and importance factors for each of these parameters are determined based on the criteria in Table 2. Cadmium has the highest importance factor due to its high toxicity potential for mammalians and plants. The $\mathrm{CI}$ of composts is calculated according to Eq.2:

Clean Index $=\frac{\sum_{j=1}^{6} D F_{j} . I F_{j}}{\sum_{j=1}^{6} I F_{j}}$

After computing FI and CI, the compost quality is determined according to the classifications in Table 3. 


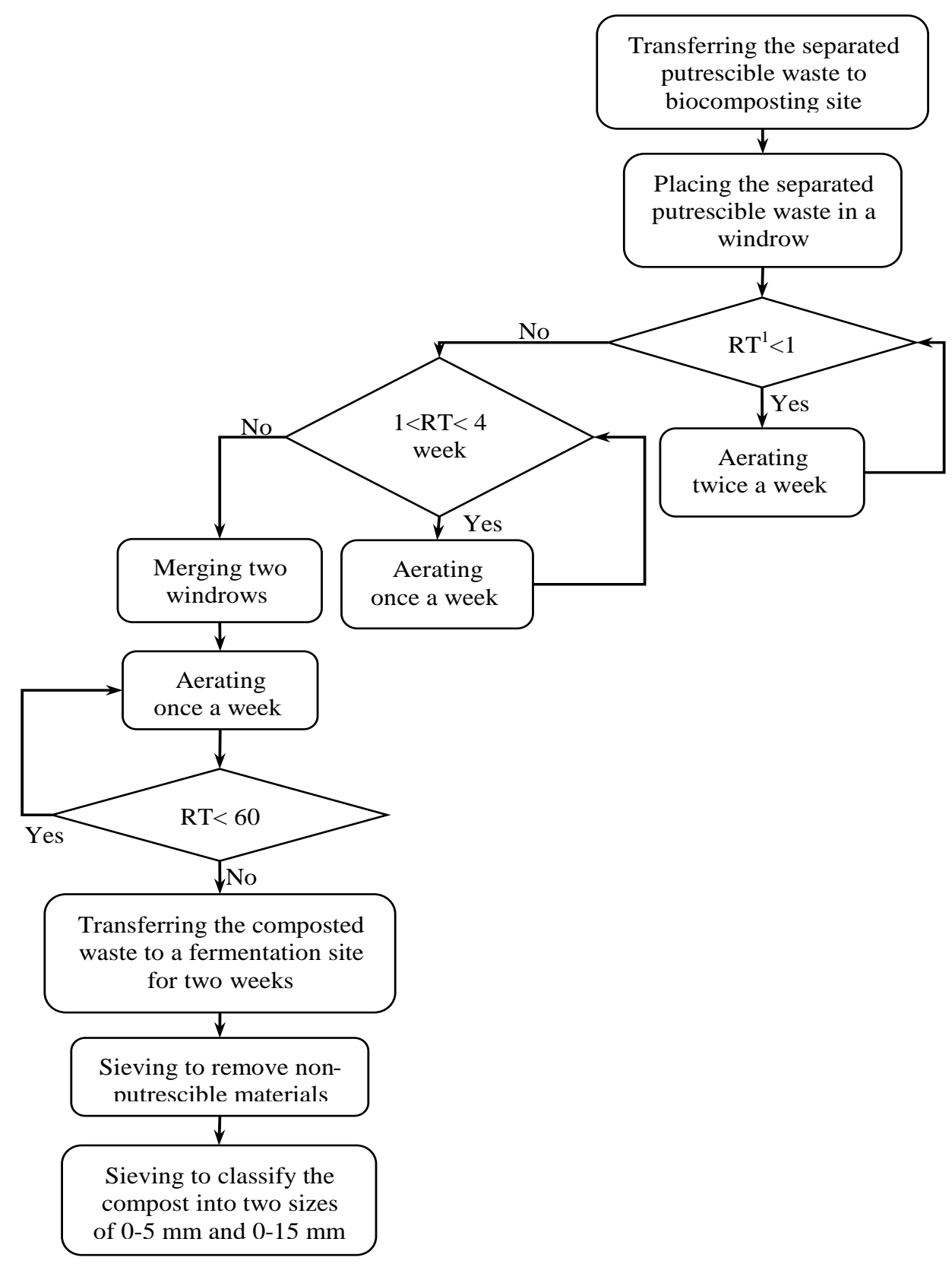

Figure. 3: Flowchart of the proposed methodology for industrial composting in Shiraz City ( ${ }^{1} \mathrm{RT}$ : retention time)

As seen, compost is divided into seven categories with regard to its quality. Composts in classes A, B, C, and D can be sold without any restriction. But the compost belonging to classes $\mathrm{E}$, $\mathrm{F}$, and $\mathrm{G}$ can only be used under special considerations. If compost has a low FI and all the heavy metal parameters are within the permissible limits, it will be non-marketable and must only be used as a soil conditioner. If compost's FI and CI are similar to class A but even one of the heavy metal parameters is beyond the permissible limit, the compost will be included in class $\mathrm{F}$ and will be non-marketable. This class of compost can be used for growing fruitless trees and ornamental plants. If compost has a suitable FI but has high heavy metal content, it will be nonmarketable and it can be used only for one time for developing and reclaiming lawns, gardens, and uncultivated lands.

\section{Results and discussions}

3.1 Chemical characterization of putrescible waste in Shiraz City

In addition to operational parameters, some chemical characteristics of putrescible waste significantly affect the effectiveness of composting process. The most important parameters are Carbon/Nitrogen $(\mathrm{C} / \mathrm{N})$ ratio, moisture content, $\mathrm{pH}$, and the amount of organic matter (OM). If these parameters are not in the range of optimal values, compost with undesirable quality and some problems such as odor and dust will be created. 
Fig 4 and Table 4 show the chemical analysis results of putrescible waste in Shiraz City. The analyses were carried out according to the standard methods (30). In addition, Table 4 gives extra information about the content of some chemical parameters such as total Carbon, Organic Carbon, ash, electrical conductivity (EC), total Nitrogen (TN), Phosphorous (P), Potassium (K), Sodium $(\mathrm{Na})$, Magnesium $(\mathrm{Mg})$, Iron $(\mathrm{Fe})$, Copper $(\mathrm{Cu})$, Manganese (Mn), Zinc (Zn), Chromium $(\mathrm{Cr})$, Lead $(\mathrm{Pb})$, Cadmium (Cd), and Nickel (Ni) in the putrescible waste of Shiraz
City.

Since microorganisms require 30 units of $\mathrm{C}$ per unit of $\mathrm{N}$, the good amount of $\mathrm{C} / \mathrm{N}$ ratio to begin the composting process is between 25 and 35 . Higher $\mathrm{C} / \mathrm{N}$ ratio contents lead to a decrease in the rate of putrescible waste decomposition, and lower contents result in the release of bad smells due to the loss of $\mathrm{N}$ in the form of ammonia or nitrous compounds. The content of $\mathrm{C} / \mathrm{N}$ ratio in the putrescible waste of Shiraz City is equal to the reasonable amount of 24.2 .

Table 1: Criteria for determining desirability and importance factors of fertilizing index (Saha et al. 2012)

\begin{tabular}{|c|c|c|c|c|c|c|c|}
\hline \multirow{2}{*}{ Fertilizing parameter } & \multirow{2}{*}{ Unit } & \multicolumn{5}{|c|}{$\mathrm{DF}^{*}$} & \multirow{2}{*}{$\mathrm{IF}^{* *}$} \\
\hline & & 5 & 4 & 3 & 2 & 1 & \\
\hline Total organic $\mathrm{C}$ & $\mathrm{g} \mathrm{g}^{-1} \% \mathrm{dw}^{*}$ & $>20.0$ & $15.1-20.0$ & $12.1-15.0$ & $9.1-12.0$ & $<9.1$ & 5 \\
\hline Total $\mathrm{N}$ & $\mathrm{g} \mathrm{g}^{-1} \% \mathrm{dw}$ & $>1.25$ & $1.01-1.25$ & $0.81-1.00$ & $0.51-0.80$ & $<0.51$ & 3 \\
\hline Total P & $\mathrm{g} \mathrm{g}^{-1} \% \mathrm{dw}$ & $>0.60$ & $0.41-0.60$ & $0.21-0.40$ & $0.11-0.2$ & $<0.11$ & 3 \\
\hline Total K & mg.kg ${ }^{-1} \mathrm{dw}$ & $>1.00$ & $0.76-1.00$ & $0.51-0.75$ & $0.26-0.50$ & $<0.26$ & 1 \\
\hline $\mathrm{C} / \mathrm{N}$ ratio & - & $<10.1$ & $10.0-15$ & $15.1-20$ & $20.1-25$ & $>25$ & 3 \\
\hline
\end{tabular}

* DF: Desirability Factor ** IF: Importance Factor

Table 2: Criteria for determining desirability and importance factors of the clean index (Saha et al. 2012)

\begin{tabular}{|c|c|c|c|c|c|c|c|c|}
\hline \multirow{2}{*}{$\mathrm{HM}^{*}$} & \multirow{2}{*}{ Unit } & \multicolumn{6}{|c|}{ DF } & \multirow{2}{*}{$\begin{array}{l}\mathrm{I} \\
\mathrm{F}\end{array}$} \\
\hline & & 5 & 4 & 3 & 2 & 1 & 0 & \\
\hline $\mathrm{Zn}$ & mg.kg ${ }^{-1} \mathrm{dw}^{*}$ & $<151$ & $151-300$ & $301-500$ & $501-700$ & $701-900$ & $>900$ & 1 \\
\hline $\mathrm{Cu}$ & mg.kg ${ }^{-1} \mathrm{dw}$ & $<51$ & $51-100$ & $101-200$ & $201-400$ & $401-600$ & $>600$ & 2 \\
\hline $\mathrm{Cd}$ & mg.kg-1 dw & $<0.3$ & $0.3-0.6$ & $0.7-1.0$ & $1.1-2.0$ & $2.0-4.0$ & $>4.0$ & 5 \\
\hline $\mathrm{Pb}$ & mg.kg ${ }^{-1} \mathrm{dw}$ & $<51$ & $51-100$ & $101-150$ & $151-250$ & $251-400$ & $>400$ & 3 \\
\hline $\mathrm{Ni}$ & mg.kg-1 dw & $<21$ & $21-40$ & 41-80 & $81-120$ & $121-160$ & $>160$ & 1 \\
\hline $\mathrm{Cr}$ & mg.kg-1 dw & $<51$ & $51-100$ & $101-150$ & $151-250$ & $251-350$ & $>350$ & 3 \\
\hline
\end{tabular}

Table 3. Compost classification with regard to its quality (Saha et al. 2012)

\begin{tabular}{|c|c|c|c|c|c|}
\hline Class & $\begin{array}{l}\text { Fertilizing } \\
\text { Index }\end{array}$ & $\begin{array}{l}\text { Clean Index }+ \text { The status of } \\
\text { heavy metal parameters }\end{array}$ & $\begin{array}{l}\text { Compost } \\
\text { quality }\end{array}$ & Selling status & Use restrictions \\
\hline A & $>3.5$ & $\begin{array}{l}>4.0+\text { All parameters of heavy } \\
\text { metals are within the } \\
\text { permissible limits }\end{array}$ & Best & Marketable & - \\
\hline B & 3.1 to 3.5 & $\begin{array}{l}>4.0+\text { All parameters of heavy } \\
\text { metals are within the } \\
\text { permissible limits }\end{array}$ & Very good & Marketable & - \\
\hline $\mathrm{C}$ & $>3.5$ & $\begin{array}{l}3.1 \text { to } 4.0+\text { All parameters of } \\
\text { heavy metals are within the } \\
\text { permissible limits }\end{array}$ & Good & Marketable & - \\
\hline D & 3.1 to 3.5 & $\begin{array}{l}3.1 \text { to } 4.0+\text { All parameters of } \\
\text { heavy metals are within the } \\
\text { permissible limits }\end{array}$ & Medium & Marketable & - \\
\hline $\mathrm{E}$ & $<3.1$ & $\begin{array}{l}\text { Any value+ All heavy metal } \\
\text { parameters are within the } \\
\text { permissible limits }\end{array}$ & $\mathrm{Bad}$ & Non-marketable & $\begin{array}{l}\text { Can be applied as a soil } \\
\text { conditioner }\end{array}$ \\
\hline $\mathrm{F}$ & $>3.5$ & $\begin{array}{l}>4.0+\text { At least one of the heavy } \\
\text { metal parameters is out of the } \\
\text { permissible limits }\end{array}$ & Bad & Non-marketable & $\begin{array}{l}\text { Can be used for growing } \\
\text { fruitless trees and ornamental } \\
\text { plants }\end{array}$ \\
\hline G & $>3.5$ & $\begin{array}{l}<4.0+\text { At least one of the heavy } \\
\text { metal parameters is out of the } \\
\text { permissible limits }\end{array}$ & Bad & Non-marketable & $\begin{array}{l}\text { Can be used only for once for } \\
\text { developing and reclaiming } \\
\text { lawns, gardens, and uncultivated } \\
\text { lands }\end{array}$ \\
\hline
\end{tabular}


Water is a vital ingredient for microorganisms to carry out their enzyme activities. The good amount of moisture is between $50 \%$ and $65 \%$. Lower moisture contents result in a significant reduction in microbial activities and higher contents lead to the appearance of anaerobic conditions. As observed, the average initial moisture content for the putrescible waste of Shiraz City is 88.1, 87.5, 67.9, and $75.4 \%$ in spring, summer, autumn, and winter, respectively. The reason for the higher moisture content in spring and summer is the high amount of fruit and vegetable waste in these seasons. However, due to an increase in temperature during the process, a large amount of moisture evaporates, and its amount can be adjusted to the acceptable range.

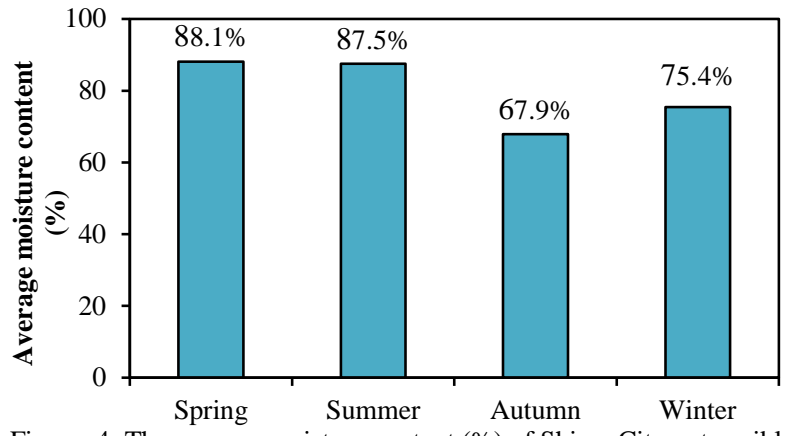

Figure. 4: The average moisture content (\%) of Shiraz City putrescible waste in each season

Since microorganisms are active in the 5.5-8.0 $\mathrm{pH}$ range, putrescible waste has to be adjusted for $\mathrm{pH}$ in this range for supporting good microbial activities during the composting process. However, a slightly acidic $\mathrm{pH}$ is favorable in the initial stage of the composting process. Therefore, the $\mathrm{pH}$ of 5.4 for the putrescible waste of Shiraz City is appropriate.

Table 4: The results of chemical analysis of Shiraz City putrescible waste

\begin{tabular}{lll}
\hline Parameter & Unit & Average content \\
\hline Organic Matter & $\mathrm{g} \mathrm{g}^{-1} \% \mathrm{dw}^{*}$ & 88.7 \\
Total Carbon & $\mathrm{g} \mathrm{g}^{-1} \% \mathrm{dw}$ & 51.1 \\
Organic Carbon & $\mathrm{g} \mathrm{g}^{-1} \% \mathrm{dw}$ & 48.5 \\
Ash & $\mathrm{g} \mathrm{g}^{-1} \% \mathrm{dw}$ & 7.7 \\
C/N ratio & - & 24.3 \\
$\mathrm{pH}$ & - & 5.4 \\
EC & $\mathrm{ds} / \mathrm{m}^{-}$ & 11.6 \\
Total Nitrogen & $\% \mathrm{dw}$ & 2.1 \\
Phosphorous & $\%$ & 0.3 \\
Potassium & $\mathrm{mg} \cdot \mathrm{kg}^{-1} \mathrm{dw}$ & $5,643.5$ \\
Calcium & $\mathrm{mg} \cdot \mathrm{kg}^{-1} \mathrm{dw}$ & 31,800 \\
Sodium & $\mathrm{mg} \cdot \mathrm{kg}^{-1} \mathrm{dw}$ & 5,345 \\
Magnesium & $\mathrm{mg} \cdot \mathrm{kg}^{-1} \mathrm{dw}$ & $2,177.5$ \\
Iron & $\mathrm{mg} \cdot \mathrm{kg}^{-1} \mathrm{dw}$ & $5,360.5$ \\
Copper & $\mathrm{mg} \cdot \mathrm{kg}^{-1} \mathrm{dw}$ & 48 \\
Manganese & $\mathrm{mg} \cdot \mathrm{kg}^{-1} \mathrm{dw}$ & 150 \\
Zinc & $\mathrm{mg} \cdot \mathrm{kg}^{-1} \mathrm{dw}$ & 328 \\
Chromium & $\mathrm{mg} \cdot \mathrm{kg}^{-1} \mathrm{dw}$ & 0 \\
Lead & $\mathrm{mg} \cdot \mathrm{kg}^{-1} \mathrm{dw}$ & 61 \\
Cadmium & $\mathrm{mg} \cdot \mathrm{kg}^{-1} \mathrm{dw}$ & 1.85 \\
Nickel & $\mathrm{mg} \cdot \mathrm{kg}^{-1} \mathrm{dw}$ & 31.4 \\
\hline
\end{tabular}

Shiraz City putrescible waste is rich in organic matter $(88.7 \%)$ and contains low ash content $(7.7 \%)$. Ash is the inorganic portion of putrescible waste and includes different inorganic minerals such as $\mathrm{Mn}, \mathrm{Mg}, \mathrm{Ca}, \mathrm{Fe}$, and $\mathrm{Na}$. During the composting process, complex organic matters are transformed to simpler components which lead to a decrease in organic matter content and an increase in ash content.

\subsection{The amount of compost production}

Between 2013 and 2015, one separation line with the capacity of $250 \mathrm{t}$ per day had been in operation. The second line with the capacity of 250 t per day has been put into operation in 2016 . Table 5 shows the separated putrescible waste from CMSW in the CMSWSC (input waste to the composting site) and the produced compost in different years.

Based on the results shown in Table 5, about 50 percent of input CMSW to the CMSWSC is transferred to the composting site. Furthermore, the weight of produced compost is about 36 percent of input putrescible waste to the composting site. It is worth mentioning that about 35 percent of rejected waste is the untorn bags of CMSW that contain putrescible waste as well. Most of the separated recyclable materials in the CMSWSC are plastics contaminated with putrescible waste. If the source separation strategy is implemented and recyclable materials are separated from putrescible wastes, not only time and energy will be saved, but also the cotamination problem of recyclable materials will also be solved.

Table 5: The mean amount of separated putrescible waste and produced compost from 2013 to 2016

\begin{tabular}{|c|c|c|c|}
\hline year & $\begin{array}{c}\text { Input wastes } \\
\text { to the } \\
\text { CMSWSC } \\
\text { (t/d) }\end{array}$ & $\begin{array}{c}\text { Separated } \\
\text { putrescible waste } \\
\text { in the CMSWSC } \\
(\mathrm{t} / \mathrm{d})\end{array}$ & $\begin{array}{l}\text { Mean produced } \\
\text { compost }(\mathrm{t} / \mathrm{d})\end{array}$ \\
\hline 2013 & 250 & 115 & 40 \\
\hline 2014 & 250 & 124 & 44 \\
\hline 2015 & 250 & 123 & 45 \\
\hline 2016 & 500 & 262 & 97 \\
\hline
\end{tabular}

\subsection{Physical and chemical analysis of the produced compost in Shiraz City}

To investigate the quality of produced compost, physical and chemical analysis were conducted at different months of 2015 and 2016. Composite method was used for sampling. A sample from the surface, a sample from the center, and a sample from the bottom of the compost stack was collected; the samples were mixed together and a quarter of mixed sample was sent to a laboratory. As the results of physical analysis show (Table 6), glass comprises a significant percentage of impurities in the produced compost due to the lack of source separation of glass. Despite many efforts to collect glass manually at the CMSWSC, a small fraction of broken glass remains in the produced compost and reduces the compost quality. Furthermore, although the weight percentage of plastic is not noticeable, its volume is considerable. Plastic in the compost, which depresses the compost market, is immediately recognized at first glance.

The use of immature compost as a soil fertilizer can have harmful effects on the soil and plants functioning due to high content of salts and unstable organic compounds (30-32). Hindering the plant growth and inducing anaerobic conditions in 
the soil are two of the most important adverse effects (32-34). Different researchers disagree on the parameters used for evaluating the degree of compost maturity (31). Some parameters used in the literature to determine a compost maturity are: $\mathrm{C} / \mathrm{N}$ ratio, $\mathrm{pH}$, electrical conductivity, moisture content, total organic matter, total nitrogen, etc (35). Table 7 shows the amount of maturity parameters for compost produced in Shiraz City and the allowance of each parameter based on compost quality standards in Iran. Considering that a first-class compost covers a compost with particle size up to $8 \mathrm{~mm}$, quality parameters of $0-5$ and $0-15$ $\mathrm{mm}$ produced compost have to be controlled based on the firstclass and second-class standards, respectively. As can be seen in Table 7, only the $\mathrm{C} / \mathrm{N}$ ratio of $0-15 \mathrm{~mm}$ compost is not within the permissible limits. However, based on the literature, an acceptable maturity is obtained for $\mathrm{C} / \mathrm{N}$ ratio less than or equal to 25.

Table 6: The physical analysis of produced compost in Shiraz City (2015-2016)

\begin{tabular}{lll}
\hline Parameters & $\begin{array}{l}\text { Weight } \\
\text { percentage for 0- } \\
5 \text { mm compost }\end{array}$ & $\begin{array}{l}\text { Weight } \\
\text { percentage for } \\
0-15 \mathrm{~mm} \\
\text { compost }\end{array}$ \\
\hline Plastic & 0.2 & 0.8 \\
Metal & 0.5 & 0.5 \\
Textile & 0.1 & 0.2 \\
$\begin{array}{l}\text { Glass } \\
\text { The total percentage } \\
\text { of impurities }\end{array}$ & 1.4 & 4.4 \\
$\begin{array}{l}\text { The allowance of } \\
\text { impurities }\end{array}$ & 2.1 & 5.9 \\
\hline
\end{tabular}

Producing a stabilized end-product is of great important in composting process. The stability of produced compost depends on its microbial respiration activity. Table 8 shows the amount of two important types of pathogen and three indicators related to the compost stability for produced compost in Shiraz City. As observed, E.coli and Salmonella pathogens in the produced compost are within the permissible limit. Three studied stability indicators are static respiration index (SRI), cumulative respiration index (CRI), and $\mathrm{C}-\mathrm{CO}_{2}$ which represent the maximum rate of oxygen uptake over $24 \mathrm{~h}$, cumulative amount of oxygen consumed after $7 \mathrm{~d}$, and the total $\mathrm{C}-\mathrm{CO}_{2}$ produced after the 7 days incubation period, respectively (36-38). More details about the calculation method of these indicators and their recommended limits for very, moderately, and least stable compost are addressed in the Komilis et al. (2011). The lower the amount of these indicators, the lower the microbial respiration activity and consequently the more stable the produced compost [36]. Based on the amount of these indicators and their recommended limits, 0-5 and 0-15 mm compost are characterized as "very stable" and "moderately stable", respectively.

\subsection{Determining the quality grade of the produced compost in Shiraz City}

Table 9 presents computed FI and CI for the produced 0-5 and 0-15 mm composts in Shiraz City. Based on the results, the produced composts in Shiraz City belong to Class $\mathrm{C}$ and have "good" quality. The produced composts have high fertilizing potential and medium heavy metal content. It is worth mentioning that the main reason for the low CI is the high cadmium content, which is the most crucial factor. If the cadmium content decreases to below $0.6 \mathrm{mg} \cdot \mathrm{kg}^{-1} \mathrm{dw}$, the CI will increase to 4 and a compost with the best quality will be produced.

Table 7: The amount of maturity parameters for produced compost in Shiraz City (2015- 2016)

\begin{tabular}{|c|c|c|c|c|c|}
\hline parameter & Unit & First class standard* & $\begin{array}{l}\text { Second class } \\
\text { standard }^{*}\end{array}$ & $\begin{array}{l}\text { 0-5 compost of } \\
\text { Shiraz City }\end{array}$ & $\begin{array}{l}\text { 0-15 compost of Shiraz } \\
\text { City }\end{array}$ \\
\hline Grain size & $\mathrm{mm}$ & $<8$ & $<20$ & $<5$ & $<15$ \\
\hline Organic matter & $\mathrm{g} \mathrm{g}^{-1} \% \mathrm{dw}^{* *}$ & $>35$ & $>25$ & 37.2 & 60.4 \\
\hline Organic Carbon & $\mathrm{g} \mathrm{g}^{-1} \% \mathrm{dw}$ & $>25$ & $>15$ & 21.9 & 31.3 \\
\hline Total Nitrogen & $\mathrm{g} \mathrm{g}^{-1} \% \mathrm{dw}$ & $1.25-1.66$ & $1-1.5$ & 1.5 & 1.3 \\
\hline Ash & g. $\mathrm{g}^{-1} \% \mathrm{dw}$ & $<50$ & $<50$ & 54.9 & 40.7 \\
\hline $\mathrm{C} / \mathrm{N}$ ratio & - & $15-20$ & $10-15$ & 15.4 & 25.4 \\
\hline $\mathrm{pH}$ & - & $6-8$ & $6-8$ & 7.8 & 7.9 \\
\hline $\mathrm{EC}$ & $\mathrm{ds} / \mathrm{m}$ & $<8$ & $<14$ & 4.6 & 4.7 \\
\hline Potassium & mg.kg-1 dw & $0.5-1.8$ & $0.5-1.8$ & 0.8 & 1.1 \\
\hline $\mathrm{Zn}$ & mg.kg-1 dw & $<1300$ & $<1300$ & 239.9 & 262.6 \\
\hline Phosphorous & g.g ${ }^{-1} \% \mathrm{dw}$ & $1-3.8$ & $0.3-3.8$ & 0.6 & 0.7 \\
\hline $\mathrm{Cd}$ & mg.kg-1 dw & $<10$ & $<10$ & 1.8 & 1.8 \\
\hline SAR & - & $<10$ & $<10$ & 0.3 & 0.3 \\
\hline $\mathrm{Cu}$ & mg.kg ${ }^{-1} \mathrm{dw}$ & $<650$ & $<650$ & 43 & 76.9 \\
\hline $\mathrm{Mn}$ & mg.kg-1 dw & - & - & 56.4 & 56 \\
\hline $\mathrm{Pb}$ & mg.kg ${ }^{-1} \mathrm{dw}$ & $<200$ & $<200$ & 50.9 & 53.8 \\
\hline $\mathrm{Ni}$ & mg.kg ${ }^{-1} \mathrm{dw}$ & $<120$ & $<120$ & 15.4 & 14 \\
\hline $\mathrm{Cr}$ & mg.kg-1 dw & $<150$ & $<150$ & 0 & 0 \\
\hline Moisture & $\% \mathrm{dw}$ & $<15$ & $<35$ & 8.8 & 23.6 \\
\hline
\end{tabular}


Table 8: The stability parameters of produced compost in Shiraz City (2015- 2016).

\begin{tabular}{lllll}
\hline Biological parameters & Unit & Iran standard & $\mathbf{0 - 5}$ mm compost & $\mathbf{0 - 1 5}$ mm compost \\
\hline E.coli & $\mathrm{MPN} / \mathrm{g}$ & $1 \times 10^{3}$ & $<3$ & 11 \\
Salmonella & $\mathrm{MPN} / 4 \mathrm{~g}$ & 3 & 0 & 0 \\
$\mathrm{SRI}_{24}$ & $\mathrm{mg} \mathrm{O}_{2} \mathrm{dry} \mathrm{kg}^{-1} \mathrm{~h}^{-1}$ & - & 70.9 & 128.4 \\
$\mathrm{CRI}$ & $\mathrm{g} \mathrm{O}_{2}$ dry kg$^{-1}$ & - & 1.5 & 3.5 \\
$\mathrm{C}_{-} \mathrm{CO}_{2}$ & $\mathrm{~g} \mathrm{C}_{2} \mathrm{CO}_{2} \mathrm{dry} \mathrm{kg}^{-1}$ & - & 1.7 & 2.4 \\
\hline
\end{tabular}

Table 9: FI, CI, and the quality of produced composts in Shiraz City.

\begin{tabular}{lcccc}
\hline Shiraz compost & Fertilizing Index & Clean Index + The status of heavy metal parameters & Class & Compost quality \\
\hline $0-5 \mathrm{~mm}$ & 4.3 & $3.9+$ All parameters of heavy metals within the standard range & C & Good quality \\
$0-15 \mathrm{~mm}$ & 4.2 & $3.6+$ All parameters of heavy metals within the standard range & C & Good quality \\
\hline
\end{tabular}

\subsection{Cost and income from industrial composting in Shiraz City}

The cost per unit weight of the produced compost in Shiraz City was calculated around 1,133 Iranian R. (0.03 US \$) in 2015 (Table 10). This cost includes the wages of workers, depreciations, and investments. As observed, much of the cost is associated with the investment in the CMSWSC construction.

The statistics of produced compost show that the weight ratio of $0-15 \mathrm{~mm}$ compost to $0-5 \mathrm{~mm}$ compost was five. The sale price of $0-15$ and $0-5 \mathrm{~mm}$ compost was 0.016 and $0.021 \mathrm{US} \$ / \mathrm{kg}$, respectively. The sale price was not changed from 2013 to 2016. Table 11 shows the average income from selling the $0-5$ and $0-15$ $\mathrm{mm}$ produced compost as well as the total income from composting in Shiraz City in different years.

Fig. 5 illustrates the difference of cost and income from composting in different years. As seen, income is less than the compost production cost. The main reasons are poor marketing strategies for selling the produced compost and the lack of loyal customer. People and farmers in Shiraz City often mistakenly know compost as "manure" or "fertilizer" while they have entirely different characteristics. They are unaware that manure may destroy young plants and continuous application of chemical fertilizer leads to a decrease in the soil nitrogen content due to leaching, an increase in the soil bulk density, and consequently soil degradation $(1,22,39,40)$. They must be informed that the use of compost as a soil conditioner leads to 1) an increase in the content of organic matter and soil moisture, and activities of soil enzymes (e.g. protease, arylsuiphatase, alkaline phosphomonoesterase, phosphodiesterase, and deaminas), soil microbial biomass, and soil respiration $(41), 2$ ) remediation of toxic pollutants such as pesticides and heavy metals in the soil by various fungi and bacteria present in the compost (42), 3) the prevention of nutrients leaching by increasing the soil aggregate stability $(43,44), 4)$ an increase in the plant growth by enhancing the uptake of required nutrients such as potassium and nitrate through the plant roots $(45,46), 5)$ an increase in the plants systemic resistance against variant environmental conditions $(7$, $47,48), 6)$ the eradication of plant diseases and soil pathogens (48), and 7) an increase in the defense system of plants (49-51).

\subsection{Assessment of composting in Shiraz City}

The most considerable opportunity of industrial composting in Shiraz City is related to the weather conditions. Semi-arid and hot climate of Shiraz City causes the monthly mean air temperature to be between 7 and $30^{\circ} \mathrm{C}$ and average relative humidity to be between $24 \%$ and $60 \%$. Another opportunity is that enough land with low groundwater level has been found around
Shiraz City which is far from residential areas, historic sites, airports, and water resources. The availability of fuel for machinery is another opportunity. The monthly cost of fuel, oil, and filter change, depreciation of tires, vehicle insurance, repairs, and maintenance is about 0.02 of each machine price. Recently, a fresh wave has been launched among people who tend to eat organic foods which may be a great opportunity for industrial composting in Shiraz City.

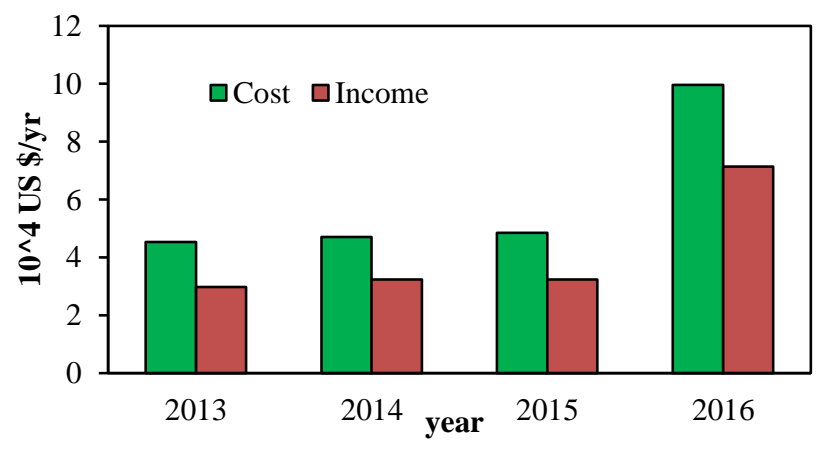

Figure 5: The cost and income from industrial composting in Shiraz City

The greatest strength of the compost production from Shiraz City CMSW is that it is a step towards sustainable development. Although many environmental projects like industrial composting in Shiraz City may initially be non-economic, they have a lot of moral values in protecting the environment, and even they have high value in the long term by protecting resources and prolonging the useful lifetime of landfill. Another strength of composting in Shiraz City is that about $70 \%$ of the generated waste is putrescible and the $\mathrm{C} / \mathrm{N}$ ratio of putrescible waste is in the acceptable range. Therefore, investment in the production of compost is wise. Also, necessary equipment for separating putrescible waste and producing compost is manufactured in the country, and there is no need to import any special equipment causing a decrease in investment levels, composting challenges, and error of the process. The development of this process creates many job positions for Shiraz citizens. In addition to those who are involved in the transportation of produced compost, marketing, and the department of composting management in the municipality, 46 workers have been employed in the sorting center and composting site. Compost production reduces the need for chemical fertilizers which may cause irreversible damage to public health and environment. 
Table 10: Cost of compost production in Shiraz City in 2015

\begin{tabular}{|c|c|c|}
\hline Cost type & Description of cost & Monthly cost (US \$) \\
\hline CMSWSC construction cost & $\begin{array}{l}\text { - Investment } \\
\text { - Depreciations and O\&M cost }\end{array}$ & $16,000.00$ \\
\hline Labor cost & $\begin{array}{l}\text { - } 5 \text { workers } \\
\text { - } 1 \text { driver }\end{array}$ & $2,453.33$ \\
\hline $\begin{array}{l}\text { Transportation cost of putrescible material within } \\
\text { the site }\end{array}$ & $\begin{array}{l}\text { - } 4 \text { truck } \\
\text { - } 1 \text { Bobcat } \\
\text { - } 1 \text { loader }\end{array}$ & $8,548.80$ \\
\hline Aeration cost & $\begin{array}{l}\text { - Investment } \\
\text { - Depreciations and O\&M cost }\end{array}$ & $6,933.33$ \\
\hline Screening cost & $\begin{array}{l}\text { - Investment } \\
\text { - Depreciations }\end{array}$ & $5,691.45$ \\
\hline Power consumption cost & $\begin{array}{l}\text { - The cost of } 15,000 \mathrm{kWh} \text { consumption per } \\
\text { month }\end{array}$ & 800.00 \\
\hline Total monthly cost (US \$) & & $40,426.91$ \\
\hline Total weight of produced compost (kg/mon) & & $1,338,333$ \\
\hline Composting cost per $\mathrm{kg}(\mathrm{US} \$)$ & & 0.03 \\
\hline
\end{tabular}

Table 11: Income from the sale of compost from 2013 to 2016

\begin{tabular}{|c|c|c|c|c|c|c|c|}
\hline Year & $\begin{array}{l}\text { Input waste to } \\
\text { CMSWSC }(\mathrm{t} / \mathrm{d})\end{array}$ & $\begin{array}{l}\text { Produced } \\
\text { compost }(\mathrm{t} / \mathrm{y})\end{array}$ & $\begin{array}{l}\text { Compost type } \\
\text { (grain size } \\
\mathrm{mm} \text { ) }\end{array}$ & $\begin{array}{l}\text { Produced } \\
\text { compost in each } \\
\text { type }(t / y)\end{array}$ & $\begin{array}{l}\text { Selling } \\
\text { price } \\
\text { (US } \$ / \mathrm{kg} \text { ) }\end{array}$ & $\begin{array}{l}\text { Income from } \\
\text { compost selling } \\
\text { (US \$) }\end{array}$ & $\begin{array}{l}\text { Total income } \\
\text { from } \\
\text { composting (US } \\
\$ \text { ) }\end{array}$ \\
\hline \multirow{2}{*}{2013} & \multirow{2}{*}{250} & \multirow{2}{*}{14,760} & $0-5$ & 2,460 & 0.016 & 39,360 & \multirow{2}{*}{297,660} \\
\hline & & & $0-15$ & 12,300 & 0.021 & 258,300 & \\
\hline \multirow{2}{*}{2014} & \multirow{2}{*}{250} & \multirow{2}{*}{16,070} & $0-5$ & 2,678 & 0.016 & 42,848 & \multirow{2}{*}{324,080} \\
\hline & & & $0-15$ & 13,392 & 0.021 & 281,232 & \\
\hline \multirow{2}{*}{2015} & \multirow{2}{*}{250} & \multirow{2}{*}{16,060} & $0-5$ & 2,677 & 0.016 & 42,832 & \multirow{2}{*}{323,875} \\
\hline & & & $0-15$ & 13,383 & 0.021 & 281,043 & \\
\hline \multirow{2}{*}{2016} & \multirow{2}{*}{500} & \multirow{2}{*}{35,405} & $0-5$ & 5,901 & 0.016 & 94,416 & \multirow{2}{*}{714,000} \\
\hline & & & $0-15$ & 29,504 & 0.021 & 619,584 & \\
\hline
\end{tabular}

The lack of administrative support and a framework for legal rules is the most important factor which threatens the industrial composting in Shiraz City. The production of compost from CMSW is still not a priority and no financial aid is allocated to this project. The potential advantages of this project will appear by an accurate planning after a long time and until then financial assistance from the government is needed to get the project off the ground. Another threat is that municipal authorities do not pay attention to the quality of the produced compost regarding compost appearance and the absence of glass and plastic. This will gradually lose the confidence of customers (end users). Another threat is related to the citizens' attitude towards compost and chemical fertilizer. Scant attention of the vast majority of people about the environment and the importance of its protection causes that people do not support buying the compost. Therefore, effective marketing plays a vital role in the success of this project.

The most considerable weakness of composting in Shiraz City is that the MSW is collected without any source separation. If the glass and plastic are separated at the source, the composting efficiency will increase significantly. The emission of greenhouse gases such as $\mathrm{CH}_{4}, \mathrm{CO}_{2}$, and $\mathrm{NH}_{3}$ is another weakness in this process. However, based on the recommendation of some researchers, $\mathrm{CO}_{2}$ does not contribute in global warming since it is generated in a biological process $(51,52)$. Since the composting site is far from residential areas, unpleasant odors and vector- borne diseases only exert adverse effects on site labors providing they do not work according to health and safety laws, codes, and regulations. The lack of shelter for the composting site leads to rapid evaporation of putrescible waste moisture. So, it is necessary to merge the windrows after four weeks so that their moisture is kept.

Based on the assessments, the following suggestions may be considered by managers who have the same experience to transform weaknesses to strengths and minimize threats to ensure the sale of produced compost:

- Planning for source separation of wastes before further development of the composting project that increases the quality of produced compost, reduces composting costs and the amount of waste transferred to the landfill, and increases the production of compost.

- Due to the glass problems in compost, it is recommended that the glass is separated in the source and collected separately or it is effectively removed from the CMSWSC.

- Marketing and introducing compost benefits to customers for increasing the incomes from composting by achieving a dynamic composting industry.

- Encouraging citizens to cooperate with the Solid Waste Management Department.

- Informing farmers about the agricultural applications of compost including keeping soil moisture, applying as a soil 
conditioner, reducing soil erosion, and mulching after seeding.

- Notifying forest development authorities about the application of compost to reduce irrigation requirements and mulching of forest lands to suppress weeds during the growing period of trees.

- Utilizing compost as good quality topsoil for quick development of lawns in the boulevards and road shoulders especially in Shiraz City which has a high demand for landscaping.

- Training fishery operators for applying compost as a factor for the rapid growth of phytoplankton and, consequently, the rapid growth of fish.

- Informing farmers about the dangers of using chemical fertilizers and animal manure.

- Implementing policies for increasing the price of chemical fertilizers.

- Ensuring the quality of produced compost for the customers.

- Advising greenhouse managers for applying the compost as a soil conditioner and reducing water requirements.

- Applying the produced compost as a biofilter at the composting site and daily cover in landfill.

The government has a vital role in achieving an efficient composting process. The government can ensure the sustainability of composting by providing loans, encouraging organic farming, and creating a favorable market.

\section{Conclusions}

This study was conducted on the industrial composting process from CMSW in Shiraz City, Iran, by a modified windrow composting method. In Shiraz City with a population of 1.5 million people, 1,000 tonnes of CMSW is collected and transferred to the processing site at Barmshoor site every day. In processing site, 500 tonnes of 1000 tonnes collected commingled solid waste is transported to CMSWSC and the rest of it is transferred to a landfill site. Data showed that about $50 \%$ of the CMSW is being separated as putrescible waste in the CMSWSC. The weight of produced compost was about $36 \%$ of input putrescible waste to the composting site. Based on the CI and FI, the produced compost in Shiraz City by the proposed method belongs to Class C and has a "good" quality. Produced compost has a high fertilizing potential and medium heavy metal content and can be sold without any restriction. Despite many efforts for manual collection of glass at the CMSWSC, a small fraction of broken glass remains in the produced compost. The weight percentage of plastic in produced compost is not noticeable, but its volume is considerable. Plastic in the compost, which depresses the compost market, is immediately recognized at first glance. Although these physical impurities in the produced compost are within the permissible limits, effective removal of glass and plastics is necessary for the production of higher quality compost. Furthermore, the stability of produced compost was assessed based on the SRI, CRI, and C-CO $\mathrm{CO}_{2}$ Index. Based on the results, 0-5 and 0-15 mm compost are characterized as "very stable" and "moderately stable", respectively. The results of this study provide valuable information to identify the positive and negative factors towards the sustainability of the composting, mitigate the uncertainties, and minimize the composting risks for the managers who have the plan of industrial composting in the cities whose wastes are not separated at the source.

\section{Ethical issue}

Authors are aware of, and comply with, best practice in publication ethics specifically with regard to authorship (avoidance of guest authorship), dual submission, manipulation of figures, competing interests, and compliance with policies on research ethics. Authors adhere to publication requirements that submitted work is original and has not been published elsewhere in any language.

\section{Competing interests}

The authors declare that there is no conflict of interest that would prejudice the impartiality of this scientific work.

\section{Authors' contribution}

All authors of this study have a complete contribution for data collection, data analyses and manuscript writing

\section{References}

1. Oviedo-Ocaña E, Dominguez I, Torres-Lozada P, MarmolejoRebellón L, Komilis D, Sanchez A. A qualitative model to evaluate biowaste composting management systems using causal diagrams: A case study in Colombia. Journal of Cleaner Production. 2016;133:201-11.

2. Elango D, Thinakaran N, Panneerselvam P, Sivanesan S. Thermophilic composting of municipal solid waste. Applied Energy. 2009;86(5):663-8.

3. Tun MM, Juchelkova D. Assessment of solid waste generation and greenhouse gas emission potential in Yangon city, Myanmar. Journal of Material Cycles and Waste Management. 2018;20(3):1397-408.

4. Ghosh A, Debnath B, Ghosh SK, Das B, Sarkar JP. Sustainability analysis of organic fraction of municipal solid waste conversion techniques for efficient resource recovery in India through case studies. Journal of Material Cycles and Waste Management. 2018;20(4):1969-85.

5. Shah GM, Tufail N, Bakhat HF, Ahmad I, Shahid M, Hammad HM, et al. Composting of municipal solid waste by different methods improved the growth of vegetables and reduced the health risks of cadmium and lead. Environmental Science and Pollution Research. 2019;26(6):5463-74.

6. Manu M, Kumar R, Garg A. Performance assessment of improved composting system for food waste with varying aeration and use of microbial inoculum. Bioresource technology. 2017;234:167-77.

7. Mu D, Horowitz N, Casey M, Jones K. Environmental and economic analysis of an in-vessel food waste composting system at Kean University in the US. Waste management. 2017;59:476-86.

8. Saha J, Panwar N, Singh M. An assessment of municipal solid waste compost quality produced in different cities of India in the perspective of developing quality control indices. Waste Management. 2010;30(2):192-201.

9. Wang X, Pan S, Zhang Z, Lin X, Zhang Y, Chen S. Effects of the feeding ratio of food waste on fed-batch aerobic composting and its microbial community. Bioresource technology. 2017;224:397-404.

10. Lou X, Nair J. The impact of landfilling and composting on greenhouse gas emissions-a review. Bioresource technology. 2009;100(16):3792-8

11. Awasthi MK, Pandey AK, Khan J, Bundela PS, Wong JW, Selvam A. Evaluation of thermophilic fungal consortium for organic municipal solid waste composting. Bioresource technology. 2014:168:214-21.

12. Malamis D, Bourka A, Stamatopoulou E, Moustakas K, Skiadi O, Loizidou M. Study and assessment of segregated biowaste composting: The case study of Attica municipalities. Journal of environmental management. 2017;203:664-9.

13. Onwosi CO, Igbokwe VC, Odimba JN, Eke IE, Nwankwoala MO, Iroh IN, et al. Composting technology in waste stabilization: on the 
methods, challenges and future prospects. Journal of environmental management. 2017;190:140-57.

14. Tai H-S, He W-H. A novel model of organic waste composting in Taiwan military community. Waste Management. 2007;27(5):66474.

15. Meyer-Kohlstock D, Hädrich G, Bidlingmaier W, Kraft E. The value of composting in Germany-Economy, ecology, and legislation. Waste management. 2013;33(3):536-9.

16. Das S, Chakraborty I, Rajesh P, Ghangrekar M. Performance Evaluation of Microbial Fuel Cell Operated with $\mathrm{Pd}$ or $\mathrm{MnO} 2$ as Cathode Catalyst and Chaetoceros Pretreated Anodic Inoculum. Journal of Hazardous, Toxic, and Radioactive Waste. 2020;24(3):04020009.

17. Das I, Das S, Dixit R, Ghangrekar M. Goethite supplemented natural clay ceramic as an alternative proton exchange membrane and its application in microbial fuel cell. Ionics. 2020:1-12.

18. Bhowmick G, Das S, Ghangrekar M, Mitra A, Banerjee R. Improved Wastewater Treatment by Combined System of Microbial Fuel Cell with Activated Carbon/TiO 2 Cathode Catalyst and Membrane Bioreactor. Journal of The Institution of Engineers (India): Series A. 2019;100(4):675-82.

19. Das S, Das S, Ghangrekar M. Quorum-sensing mediated signals: A promising multi-functional modulators for separately enhancing algal yield and power generation in microbial fuel cell. Bioresource technology. 2019;294:122138.

20. Das S, Ghangrekar M. Value added product recovery and carbon dioxide sequestration from biogas using microbial electrosynthesis. 2018.

21. Soares MA, Quina MJ, Reis MS, Quinta-Ferreira R. Assessment of co-composting process with high load of an inorganic industrial waste. Waste management. 2017;59:80-9.

22. Qian X, Shen G, Wang Z, Guo C, Liu Y, Lei Z, et al. Co-composting of livestock manure with rice straw: Characterization and establishment of maturity evaluation system. Waste management. 2014;34(2):530-5

23. Lim SL, Lee LH, Wu TY. Sustainability of using composting and vermicomposting technologies for organic solid waste biotransformation: recent overview, greenhouse gases emissions and economic analysis. Journal of Cleaner Production. 2016;111:262-78.

24. Saer A, Lansing S, Davitt NH, Graves RE. Life cycle assessment of a food waste composting system: environmental impact hotspots. Journal of Cleaner Production. 2013;52:234-44.

25. Castaldi P, Garau G, Melis P. Maturity assessment of compost from municipal solid waste through the study of enzyme activities and water-soluble fractions. Waste Management. 2008;28(3):534-40.

26. Das M, Uppal H, Singh R, Beri S, Mohan K, Gupta VC, et al. Cocomposting of physic nut (Jatropha curcas) deoiled cake with rice straw and different animal dung. Bioresource technology. 2011;102(11):6541-6.

27. Siles-Castellano AB, López MJ, López-González JA, Suárez-Estrella F, Jurado MM, Estrella-González MJ, et al. Comparative analysis of phytotoxicity and compost quality in industrial composting facilities processing different organic wastes. Journal of Cleaner Production. 2020;252:119820.

28. Cesaro A, Conte A, Belgiorno V, Siciliano A, Guida M. The evolution of compost stability and maturity during the full-scale treatment of the organic fraction of municipal solid waste. Journal of environmental management. 2019;232:264-70.

29. Theepharaksapan S, Chiemchaisri C, Chiemchaisri W, Yamamoto K. Removal of pollutants and reduction of bio-toxicity in a full scale chemical coagulation and reverse osmosis leachate treatment system. Bioresource Technology. 2011;102(9):5381-8.

30. Federation WE, Association APH. Standard methods for the examination of water and wastewater. American Public Health Association (APHA): Washington, DC, USA. 2005.

31. Guo R, Li G, Jiang T, Schuchardt F, Chen T, Zhao Y, et al. Effect of aeration rate, $\mathrm{C} / \mathrm{N}$ ratio and moisture content on the stability and maturity of compost. Bioresource Technology. 2012;112:171-8.
32. Huang G, Wong J, Wu Q, Nagar B. Effect of C/N on composting of pig manure with sawdust. Waste management. 2004;24(8):805-13.

33. Juárez MF-D, Prähauser B, Walter A, Insam H, Franke-Whittle IH Co-composting of biowaste and wood ash, influence on a microbially driven-process. Waste management. 2015;46:155-64.

34. Chen L, De Haro M, Moore A, Falen C. The Composting Process: Dairy Compost Production and Use in Idaho CIS 1179. University of Idaho. 2011.

35. Raut M, William SP, Bhattacharyya J, Chakrabarti T, Devotta S. Microbial dynamics and enzyme activities during rapid composting of municipal solid waste-a compost maturity analysis perspective. Bioresource Technology. 2008;99(14):6512-9.

36. Komilis D, Kontou I, Ntougias S. A modified static respiration assay and its relationship with an enzymatic test to assess compost stability and maturity. Bioresource technology. 2011;102(10):5863-72.

37. Adani F, Gigliotti G, Valentini F, Laraia R. Respiration index determination: a comparative study of different methods. Compost science \& utilization. 2003;11(2):144-51.

38. Ponsá S, Gea T, Sánchez A. The effect of storage and mechanical pretreatment on the biological stability of municipal solid wastes. Waste management. 2010;30(3):441-5.

39. El Ouaqoudi FZ, El Fels L, Lemée L, Amblès A, Hafidi M. Evaluation of lignocelullose compost stability and maturity using spectroscopic (FTIR) and thermal (TGA/TDA) analysis. Ecological Engineering. 2015;75:217-22.

40. Swarnam T, Velmurugan A, Pandey SK, Roy SD. Enhancing nutrient recovery and compost maturity of coconut husk by vermicomposting technology. Bioresource technology. 2016;207:76-84.

41. Ghosh S, Ow LF, Wilson B. Influence of biochar and compost on soil properties and tree growth in a tropical urban environment. International journal of environmental science and technology. 2015;12(4):1303-10.

42. Bhattacharyya P, Chakraborty A, Bhattacharya B, Chakrabarti K. Evaluation of MSW compost as a component of integrated nutrient management in wetland rice. Compost Science \& Utilization. 2003;11(4):343-50.

43. Hargreaves J, Adl M, Warman P. A review of the use of composted municipal solid waste in agriculture. Agriculture, Ecosystems \& Environment. 2008;123(1-3):1-14.

44. Chen M, Xu P, Zeng G, Yang C, Huang D, Zhang J. Bioremediation of soils contaminated with polycyclic aromatic hydrocarbons, petroleum, pesticides, chlorophenols and heavy metals by composting: applications, microbes and future research needs Biotechnology Advances. 2015;33(6):745-55.

45. Waqas M, Nizami A, Aburiazaiza A, Barakat M, Ismail I, Rashid M. Optimization of food waste compost with the use of biochar. Journal of environmental management. 2018;216:70-81.

46. Keeling A, McCallum K, Beckwith C. Mature green waste compost enhances growth and nitrogen uptake in wheat (Triticum aestivum L.) and oilseed rape (Brassica napus L.) through the action of waterextractable factors. Bioresource Technology. 2003;90(2):127-32.

47. Canellas LP, Olivares FL. Physiological responses to humic substances as plant growth promoter. Chemical and Biological Technologies in Agriculture. 2014;1(1):3.

48. Monda H, Cozzolino V, Vinci G, Spaccini R, Piccolo A. Molecular characteristics of water-extractable organic matter from different composted biomasses and their effects on seed germination and early growth of maize. Science of the Total Environment. 2017;590:40-9.

49. Cayuela M, Millner P, Meyer S, Roig A. Potential of olive mill waste and compost as biobased pesticides against weeds, fungi, and nematodes. Science of the total environment. 2008;399(1-3):11-8.

50. St. Martin C, Brathwaite R. Compost and compost tea: Principles and prospects as substrates and soil-borne disease management strategies in soil-less vegetable production. Biological agriculture \& horticulture. 2012;28(1):1-33

51. Pane C, Celano G, Villecco D, Zaccardelli M. Control of Botrytis cinerea, Alternaria alternata and Pyrenochaeta lycopersici on tomato with whey compost-tea applications. Crop Protection. 2012;38:80-6. 
52. Carballo T, Gil M, Calvo L, Morán A. The influence of aeration system, temperature and compost origin on the phytotoxicity of compost tea. Compost science \& utilization. 2009;17(2):127-39. 